\title{
Significant Association of Serum Adiponectin and Creatine Kinase-MB Levels in ST-Segment Elevation Myocardial Infarction
}

\author{
Tomoaki Natsukawa ${ }^{1,2}$, Norikazu Maeda ${ }^{1,3}$, Shiro Fukuda ${ }^{1}$, Masaya Yamaoka ${ }^{1}$, Yuya Fujishima ${ }^{1}$, \\ Hirofumi Nagao ${ }^{1}$, Fumi Sato ${ }^{1}$, Hitoshi Nishizawa ${ }^{1}$, Hirotaka Sawano ${ }^{2}$, Yasuyuki Hayashi², \\ Tohru Funahashi ${ }^{1,3}$, Tatsuro $\mathrm{Kai}^{2}$ and lichiro Shimomura ${ }^{1}$ \\ ${ }^{1}$ Department of Metabolic Medicine, Graduate School of Medicine, Osaka University, Osaka, Japan \\ ${ }^{2}$ Senri Critical Care Medical Center, Osaka Saiseikai Senri Hospital, Osaka, Japan \\ ${ }^{3}$ Department of Metabolism and Atherosclerosis, Graduate School of Medicine, Osaka University, Osaka, Japan
}

\begin{abstract}
Aims: Adiponectin, an adipocyte-specific secretory protein, abundantly exists in the blood stream while its concentration paradoxically decreases in obesity. Hypoadiponectinemia is one of risks of cardiovascular diseases. However, impact of serum adiponectin concentration on acute ischemic myocardial damages has not been fully clarified. The present study investigated the association of serum adiponectin and creatine kinase (CK)-MB levels in subjects with ST-segment elevation myocardial infarction (STEMI).

Methods: This study is a physician-initiated observational study and is also registered with the University Hospital Medical Information Network (Number: UMIN 000014418). Patients were admitted to Senri Critical Care Medical Center, given a diagnosis of STEMI, and treated by primary percutaneous coronary intervention (PCI). Finally, 49 patients were enrolled and the association of serum adiponectin, CK-MB, and clinical features were mainly analyzed.

Results: Serum adiponectin levels decreased rapidly and reached the bottom at 24 hours after recanalization. Such reduction of serum adiponectin was inversely correlated with the area under the curve (AUC) of serum CK-MB $(p=0.013)$. Serum adiponectin concentrations were inversely correlated with AUC of serum CK-MB. In multivariate analysis, serum adiponectin concentration on admission $(p=0.002)$ and collateral $(p=0.037)$ were significantly and independently correlated with serum AUC of CK-MB.

Conclusion: Serum AUC of CK-MB in STEMI subjects was significantly associated with serum adiponectin concentration on admission and reduction of serum adiponectin levels from baseline to bottom. The present study may provide a possibility that serum adiponectin levels at acute phase are useful in the prediction for prognosis after PCI-treated STEMI subjects.
\end{abstract}

\section{See editorial vol. 24: 788-790}

Key words: Adiponectin, Myocardial infarction, Acute coronary syndrome, CK-MB, Infarct size

Copyright@2017 Japan Atherosclerosis Society

This article is distributed under the terms of the latest version of CC BY-NC-SA defined by the Creative Commons Attribution License.

\section{Introduction}

Adiponectin is characterized as an overabundance

Address for correspondence: Norikazu Maeda, Department of Metabolic Medicine, Department of Metabolism and Atherosclerosis, Graduate School of Medicine, Osaka University, 2-2-B5, Yamada-oka, Suita, Osaka 565-0871, Japan

E-mail: norikazu_maeda@endmet.med.osaka-u.ac.jp

Received: September 25, 2016

Accepted for publication: November 30, 2016 in the circulating blood stream and a paradoxical decrease in obesity despite an adipocyte-specific secretory protein ${ }^{1-3)}$. Accumulating experimental evidence demonstrates the anti-atherosclerotic and anti-diabetic effects of adiponectin ${ }^{4}$. Adiponectin especially suppresses a series of progressive process of atherosclerosis, such as adhesion of monocytes to endothelial cells ${ }^{5}$, proliferation of vascular smooth muscle cells ${ }^{6}$, and foam cell formation of macrophages ${ }^{7)}$. Interestingly, our recent immunohistochemical and immunoelec- 
tron microscopic analyses showed that adiponectin protein was detected in endothelial cells in normal aorta, while it was observed not only in endothelial cells but also on the surface of synthetic smooth muscle cells and monocytes adherent to endothelial cells in atherosclerotic vasculature ${ }^{8)}$.

Importantly, increasing clinical evidences support the anti-atherosclerotic property of adiponectin. Low circulating adiponectin level (hypoadiponectinemia) should be one of the risks for atherosclerotic cardiovascular diseases ${ }^{1-4}$. Several clinical studies demonstrated the association of hypoadiponectinemia and ischemic heart diseases ${ }^{9,10)}$. Hypoadiponectinemia was also associated with coronary lesion complexity ${ }^{11)}$. However, few reports have investigated the serial change in circulating adiponectin level in the acute phase of acute coronary syndrome (ACS). Kojima et al. demonstrated that adiponectin significantly decreased around 24-72 hours after hospitalization with acute myocardial infarction (AMI) ${ }^{12)}$.

Serum creatine kinase (CK)-MB has been clinically used for diagnosis of AMI and estimation of myocardial infarction size ${ }^{13)}$. Peak CK-MB and the area under the curve (AUC) of serum CK-MB have been shown to predict mortality in subjects with primary percutaneous coronary intervention (PCI)treated ST-segment elevation myocardial infarction $(\text { STEMI })^{14-16)}$. However, the correlation between adiponectin and CK-MB has not been examined in patients with STEMI treated by primary PCI. The present study investigated the serial change of serum adiponectin level and the association of adiponectin and CK-MB in STEMI subjects who underwent primary PCI.

\section{Methods}

\section{Subjects}

The present study is an observational study titled "Study for correlation of organ injury with transition of adiponectin in acute and critical illness (RESPECT ALL)" and a physician-initiated, non-company sponsored single-center registry. Patients were admitted to Senri Critical Care Medical Center in Osaka Saiseikai Senri Hospital due to STEMI and treated by primary PCI from November 2013 to February 2015. After excluding 37 patients who were unable to sign the written informed consent or refused study participation, 9 patients who were transported under cardiac arrest, 2 patients who had previous old myocardial infarction, and 2 patients who were maintained by hemodialysis; 49 participants were enrolled and analyzed in the current study. The study protocol complied with the guidelines for epidemiologic studies issued by the Ministry of Health, Labour, and Welfare of Japan was approved by the human ethics committees of Osaka Saiseikai Senri Hospital and Osaka University Hospital and was also registered with the University Hospital Medical Information Network (Number: UMIN 000014418).

All patients received the standard care available at the hospital, and no subject underwent any type of experimental intervention. Within 12 hours from the onset of chest pain, PCI was performed immediately after administration with $300 \mathrm{mg}$ of clopidogrel and $200 \mathrm{mg}$ of aspirin as the loading dose and intravenous injection of heparin at 8000 units, and a stent was successfully implanted in culprit lesion in most of patients by experienced interventionists. Thrombolysis in myocardial infarction (TIMI) flow grade at initial coronary angiography was evaluated as described previously ${ }^{17)}$. Collateral flow was defined according to Rentrop classification ${ }^{18)}$. After PCI, all patients received dual anti-platelet therapy (clopidogrel and aspirin), statins, and angiotensin-converting enzyme (ACE) inhibitors. Thrombectomy and intracoronary administration with vasodilators were left to the discretion of the interventional cardiologist.

\section{Data Collection and Blood Sampling}

The baseline data for the patients included age, sex, body mass index (BMI), coronary risk factors (diabetes mellitus, dyslipidemia, hypertension, and smoking habit), comorbidities (hyperuricemia, chronic kidney diseases, malignancy, cerebral infarction, chronic heart failure, and inflammatory diseases), previous medication, and time from onset to admission.

Blood samples for serum were allowed to coagulate at room temperature for $30 \mathrm{~min}$, followed by centrifuged at $4000 \mathrm{rpm}$ for $10 \mathrm{~min}$, and stored at $-80^{\circ} \mathrm{C}$. Serum adiponectin concentration was measured by enzyme-linked immunosorbent assay (ELISA) (Otsuka Pharmaceutical Co., Ltd.). Serum CK-MB on admission and at 3, 6, 12, 24, 48, and 72 hours was measured by immunological inhibition method (ShinoTest Corporation, Beckman Coulter, Inc.). AUC of serum CK-MB was calculated as a sum of the trapezoid areas [a vertical axis: CK-MB (U/L), a horizontal axis: hour].

\section{Statistical Analyses}

Continuous variables, which were not normally distributed, were demonstrated as medians and interquartile ranges. Categorical variables were shown as counts and percentages. The Wilcoxon signed-rank test was used to compare continuous variables of \% serum adiponectin concentration on admission and at 3, 6, 12, 24, 48, 72, and 168 hours. The Spearman's 
rank correlation analysis was used to calculate correlation coefficient of parameters. The Jonckheere-Terpstra test was used to examine trend of AUC for $\mathrm{CK}-\mathrm{MB}$ in each quartile group of serum adiponectin concentration on admission. The forced-entry logistic regression analysis was used to calculate the $t$-values of parameters. The significance level was set at $p<0.05$. The software program SPSS Statistics 21 for Windows (IBM Japan, Tokyo) was used to analyze all data.

\section{Results}

\section{Baseline Characteristics}

The baseline clinical characteristics are shown in Table 1. The median age was 67 old and $69.4 \%$ of patients were men. The median BMI was $23.7 \mathrm{~kg} / \mathrm{m}^{2}$, indicating that study population was not obese subjects. As for coronary risk factors, prevalence of diabetes mellitus, dyslipidemia, hypertension, current smoker, and ex-smoker were 34.7\%, 77.6\%, 57.1\%, 40.8\%, and $22.4 \%$, respectively. As for comorbidities, $20.4 \%$ of patients had hyperuricemia, and $16.3 \%$ of patients had renal insufficiency (eGFR $<60 \mathrm{ml} / \mathrm{min} / 1.73 \mathrm{~m}^{2}$ ). No patient had a history of cerebral infarction, chronic heart failure, or inflammatory diseases. Among previous medications, the number of subjects treated with antihypertensive agents was relatively high, but that of patients treated with antidiabetic and/or lipid-lowering agents was low despite high frequency of diabetes and dyslipidemia.

Median time from onset of symptom to door was 88 minutes and the time of onset-to-recanalization was 124 minutes. As for culprit lesion of STEMI, $28.6 \%$ were right coronary artery (RCA), $2.0 \%$ was left main coronary artery (LMCA), 59.2\% were left anterior descending coronary artery (LAD), and 10.2\% were left circumflex coronary artery (LCx). Collateral arteries of Rentrop grade 1-3 were observed in $18.4 \%$ of patients. As for the initial TIMI flow grade, $83.7 \%$ were grade $0,2.0 \%$ were grade $1,10.2 \%$ were grade 2 , and $4.1 \%$ were grade 3 . As for stent use, drug-eluting stent (DES) was implanted in $87.7 \%$ of patients, bare metal stent (BMS) was used in $8.2 \%$ of patients, and no stent was used in $4.1 \%$ of patients. After primary PCI, complete and partial ST-segment resolutions were obtained in $44.9 \%$ and $24.5 \%$ of patients, respectively.

\section{Change of Serum Adiponectin Concentrations}

We first examined the sequential changes of serum adiponectin concentrations in patients with STEMI (Fig. 1). The \% change of serum adiponectin concentration from baseline (on admission) was adopted since serum adiponectin levels were widely distributed. Interestingly, serum adiponectin levels decreased rapidly and reached the bottom at 24 hours after recanalization. They gradually and slowly increased from 24 to 168 hours (from Day 1 to Day 7). Compared to the baseline, the $\%$ changes of serum adiponectin concentration were $87.9 \%$ [range: $82.7-$ 97.1] $(p<0.0001)$ at 3 hours, $89.7 \%$ [range: $83.6-$ 96.8] $(p<0.0001)$ at 6 hours, $84.5 \%$ [range: $78.3-$ 93.8] $(p<0.0001)$ at 12 hours, $81.4 \%$ [range: $74.0-$ 87.6] $(p<0.0001)$ at 24 hours, $82.0 \%$ [range: $73.6-$ 95.0] $(p<0.0001)$ at 48 hours, $83.1 \%$ [range: $75.2-$ 92.0] $(p<0.0001)$ at 72 hours, and $85.3 \%$ [range: $74.8-94.8](p<0.001)$ at 168 hours.

\section{Correlations between Serum Adiponectin Concen- tration and Serum AUC of CK-MB}

We next examined the correlation between serum adiponectin concentration and serum AUC of CK-MB, an indicator of myocardial damage ${ }^{13)}$. As shown in Fig. 2, serum adiponectin concentrations were negatively correlated with serum AUC of CK-MB at baseline (on admission) $(r=-0.492, p<0.001$; Fig. 2A), at 24 hours $(r=-0.459, p<0.001$; Fig. 2B), and at 168 hours $(r=-0.474, p<0.001$; Fig. $2 C)$. The minimum values of serum adiponectin concentration (Minadiponectin) were also inversely correlated with serum AUC of CK-MB $(r=-0.477, p<0.001$; Fig. 2D).

Association between serum AUC of CK-MB and difference from baseline to Min-adiponectin [ $\Delta$ adiponectin; (Min-adiponectin) - (baseline adiponectin)] was also analyzed as in Fig. 3A. Interestingly, serum AUC of CK-MB was inversely correlated with $\Delta$ adiponectin. $(r=-0.351, p=0.013)$.

Study population was divided into 4 groups in proportion to serum adiponectin level at baseline $(\mathrm{Q} 1$, $1.6-3.1 \mu \mathrm{g} / \mathrm{mL}$; Q2, 4.3-6.1 $\mathrm{\mu g} / \mathrm{mL} ; \mathrm{Q} 3,6.2-8.6$ $\mu \mathrm{g} / \mathrm{mL}$; Q4, 9.2-26.5 $\mu \mathrm{g} / \mathrm{mL}$ ). Fig.3B shows the association between serum AUC of CK-MB and each quartile. Subjects in the lowest baseline adiponectin group (Q1) showed the highest serum AUC of CK-MB. Serum AUC of CK-MB was significantly reduced from the highest quartile (Q1) to the lowest quartile (Q4) $(p<0.001$ for trend).

\section{Correlations between Serum AUC of CK-MB and Clinical Parameters}

We finally investigated correlations between serum AUC of CK-MB and clinical parameters (Table 2). Serum adiponectin concentration at baseline (on admission) and age were negatively associated with serum AUC of CK-MB $(p<0.001$ and $p=0.006$, respectively). Male gender was positively associated with serum AUC of CK-MB ( $p=0.095)$. To assess the determinants for serum AUC of CK-MB, the forced- 
Table 1. Baseline characteristics

\begin{tabular}{|c|c|c|c|}
\hline Age, years & & & $67(56,75)$ \\
\hline Male, \% (n) & & & $69.4(34 / 49)$ \\
\hline BMI, $\mathrm{kg} / \mathrm{m}^{2}$ & & & $23.7(22.1,27.3)$ \\
\hline \multirow[t]{5}{*}{ Coronary Risk Factors } & Diabetes Mellitus, \% (n) & & $34.7(17 / 49)$ \\
\hline & Dyslipidemia, \% (n) & & $77.6(38 / 49)$ \\
\hline & Hypertension, \% (n) & & $57.1(28 / 49)$ \\
\hline & Smoking & Current smoker, \% (n) & $40.8(20 / 49)$ \\
\hline & & Ex-smoker, \% (n) & $22.4(11 / 49)$ \\
\hline \multirow[t]{6}{*}{ Comorbidities } & Hyperuricemia, \% (n) & & $20.4(10 / 49)$ \\
\hline & eGFR $<60, \%(n)$ & & $16.3(8 / 49)$ \\
\hline & Malignancy, \% (n) & & $4.1(2 / 49)$ \\
\hline & Cerebral infarction, \% (n) & & $0.0(0 / 49)$ \\
\hline & Chronic heart failure, \% (n) & & $0.0(0 / 49)$ \\
\hline & Inflammatory disease, $\%$ (n) & & $0.0(0 / 49)$ \\
\hline \multirow[t]{12}{*}{ Medications } & $\mathrm{TZD}, \%(\mathrm{n})$ & & $0.0(0 / 49)$ \\
\hline & DPP4-I, \% (n) & & $8.1(4 / 49)$ \\
\hline & Biguanide, \% (n) & & $2.0(1 / 49)$ \\
\hline & Sulfonylurea, \% (n) & & $4.1(2 / 49)$ \\
\hline & Insulin, \% (n) & & $0.0(0 / 49)$ \\
\hline & Calcium channel blocker, \% (n) & & $28.6(14 / 49)$ \\
\hline & ACE-I/ARB, \% (n) & & $32.7(16 / 49)$ \\
\hline & Beta-blocker, \% (n) & & $4.1(2 / 49)$ \\
\hline & Statin, \% (n) & & $22.4(11 / 49)$ \\
\hline & Eicosapentaenoic acid, \% (n) & & $0.0(0 / 49)$ \\
\hline & Fibrate, \% (n) & & $0.0(0 / 49)$ \\
\hline & Antiplatelet drug, \% (n) & & $4.1(2 / 49)$ \\
\hline \multirow[t]{2}{*}{ Time } & Onset to Door Time, min & & $88(56,190)$ \\
\hline & Onset to Recanalization Time, min & & $124(95,270)$ \\
\hline \multirow[t]{4}{*}{ Culprit/Affected Vessel } & $\mathrm{RCA}, \%(\mathrm{n})$ & & $28.6(14 / 49)$ \\
\hline & LMCA, \% (n) & & $2.0(1 / 49)$ \\
\hline & LAD, \% (n) & & $59.2(29 / 49)$ \\
\hline & $\mathrm{LCx}, \%(\mathrm{n})$ & & $10.2(5 / 49)$ \\
\hline Collateral, \% (n) & & & $18.4(9 / 49)$ \\
\hline \multirow[t]{4}{*}{ Initial TIMI flow grade } & $0, \%(\mathrm{n})$ & & $83.7(41 / 49)$ \\
\hline & $1, \%(\mathrm{n})$ & & $2.0(1 / 49)$ \\
\hline & $2, \%(\mathrm{n})$ & & $10.2(5 / 49)$ \\
\hline & $3, \%(\mathrm{n})$ & & $4.1(2 / 49)$ \\
\hline \multirow[t]{3}{*}{ Stent } & DES, \% (n) & & $87.7(43 / 49)$ \\
\hline & BMS, \% (n) & & $8.2(4 / 49)$ \\
\hline & None, \% (n) & & $4.1(2 / 49)$ \\
\hline \multirow[t]{3}{*}{ ST resolution } & Complete, \% (n) & & $44.9(22 / 49)$ \\
\hline & Partial, \% (n) & & $24.5(12 / 49)$ \\
\hline & None, \% (n) & & $30.6(15 / 49)$ \\
\hline
\end{tabular}

Data are median and inter quartile ranges or percentage of subjects. BMI: body mass index, eGFR: estimated glomerular filtration rate, TZD: Thiazolidine derivative, DPP4-I: dipeptidyl peptidase-4 inhibitor, ACE-I: angiotensin converting enzyme inhibitor, ARB: angiotensin II receptor blocker, RCA: right coronary artery, LMCA: left main coronary artery, LAD: left anterior descending coronary artery, LCx: left circumflex coronary artery, TIMI: thrombolysis in myocardial infarction trial, DES: drug eluting stent, BMS: bare metal stent. 


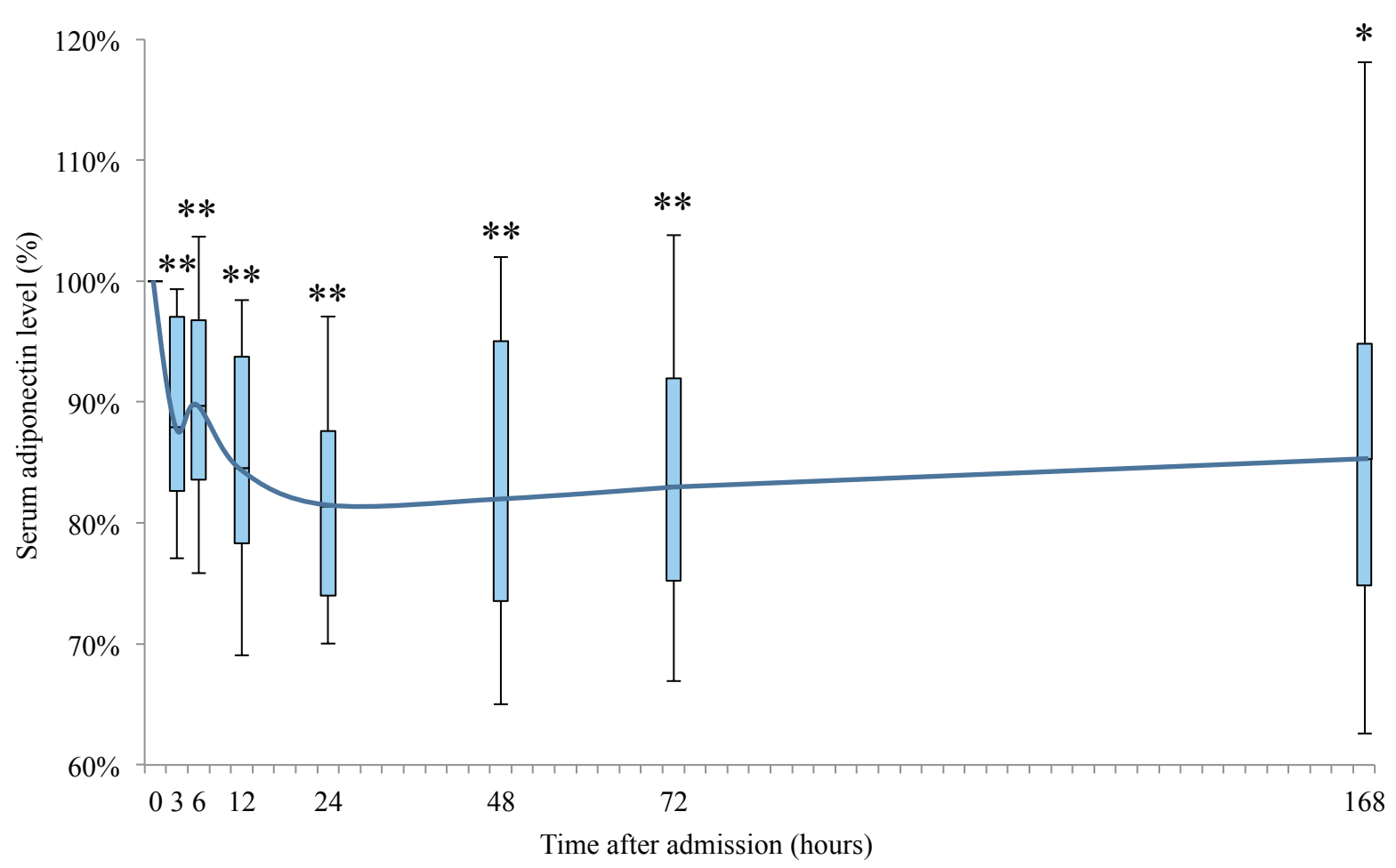

Fig. 1. Change of serum adiponectin levels.

Serum adiponectin concentration on admission was set at $100 \%$. Curve shows the connected median, box shows the interquartile range, bar shows the 10th to 90th percentile of 49 patients. ${ }^{*} p<0.001,{ }^{* *} p<0.0001$, compared with the $100 \%$ on admission

entry logistic regression analysis was performed including all clinical variables (Multivariate 1 in Table 2) or the confined variables relating to infarction size, such as culprit lesion, initial TIMI flow grade, collateral, and onset-to-recanalization time (Multivariate 2 in Table 2). Multivariate 1 demonstrated that serum adiponectin concentration on admission was significantly and independently correlated with serum AUC of CK-MB $(t=-2.086, p=0.045)$. In Multivariate 2, serum adiponectin concentration on admission $(t=$ -3.283, $p=0.002)$ and collateral $(t=-2.149, p=$ $0.037)$ were significantly and independently correlated with serum AUC of CK-MB.

\section{Discussion}

As shown in Fig. 1, serum adiponectin decreased from admission to 24 hours and gradually recovered to baseline after acute clinical phase. Such change of serum adiponectin was similar to previous studies in subjects with AMI $(n=35)^{12)}$ and LAD-based STEMI $(n=98)^{19)}$. Similar to human subjects, such reduction of plasma adiponectin was also observed in myocardial ischemia-reperfusion (I-R) injury murine model ${ }^{20,21)}$. Interestingly, transient accumulation of the exoge- nously administered adiponectin in heart tissue was shown in adiponectin knockout mice with myocardial I-R injury ${ }^{20)}$. Our experimental reports demonstrated that adiponectin protein existed in the aorta ${ }^{8,22)}$ and heart tissues ${ }^{23)}$, indicating that circulating adiponectin accumulates in cardiovascular tissues. We recently showed that T-cadherin is a critical player for tissue accumulation of adiponectin, for example, in T-cadherin knockout mice, adiponectin was not detected in cardiovasculature despite the 4- to 5-fold increase of circulating adiponectin ${ }^{24)}$. In human subjects, we cannot examine the accumulation of adiponectin in injured tissues and/or vessels under ischemic condition, but a transient decline of serum adiponecitn may suggest the accumulation of adiponectin in injured tissues. The tissue accumulating adiponectin may exhibit a cardiovascular protective role. Importantly, as shown in Fig. 3A, a transient decline of serum adiponecitn was negatively correlated with serum AUC of CK-MB, indicating a possibility of abundant accumulation of adiponectin protected from myocardial damage and resulting in reduction of infarct size.

Animal models of myocardial infarction indicated that adiponectin protects against myocardial damage by enhancing AMP-activated protein kinase 
A

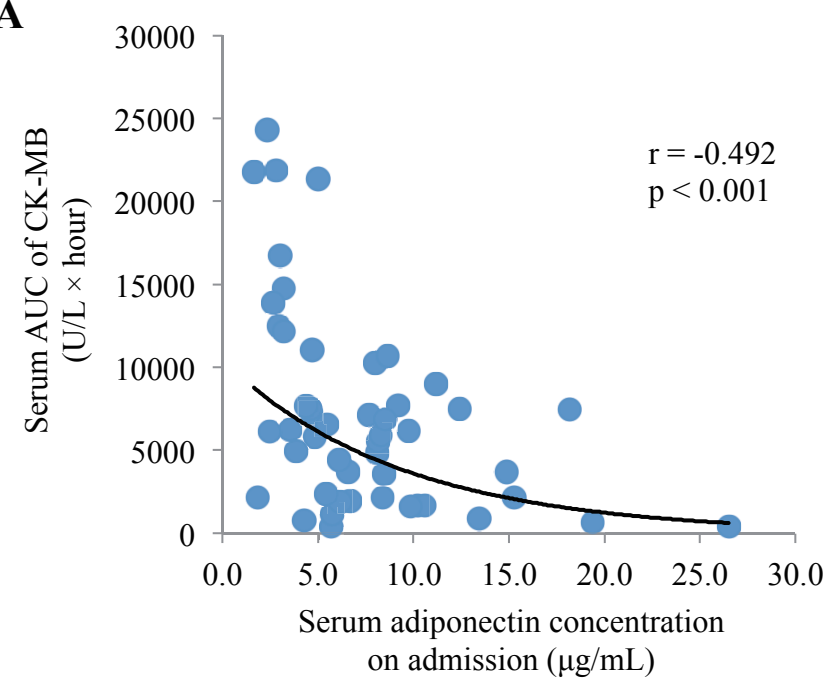

C

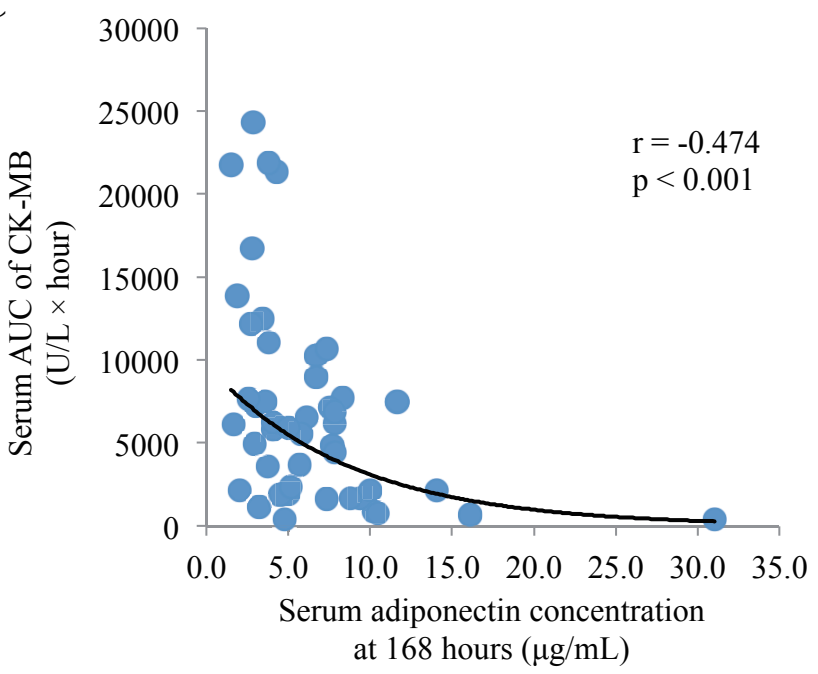

B

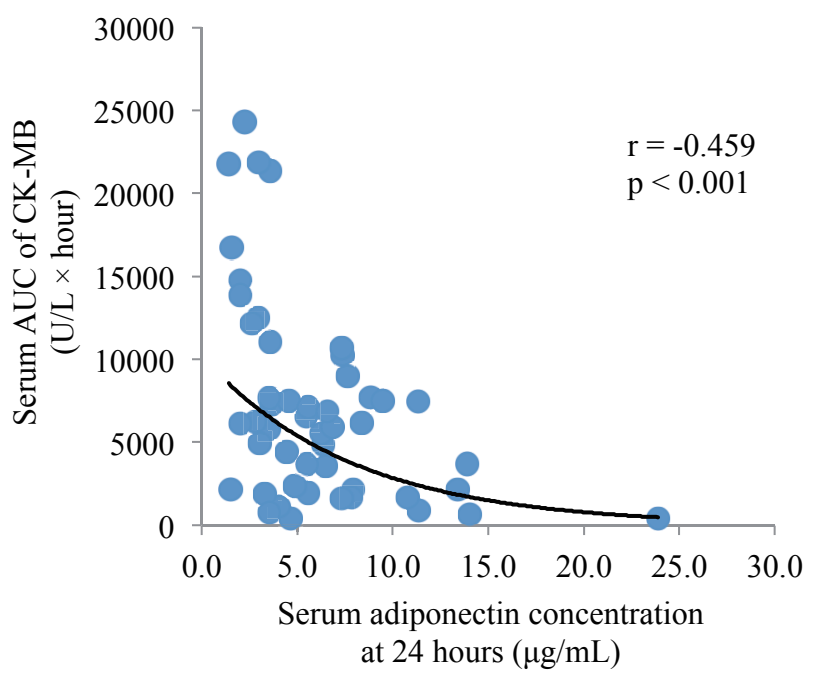

D

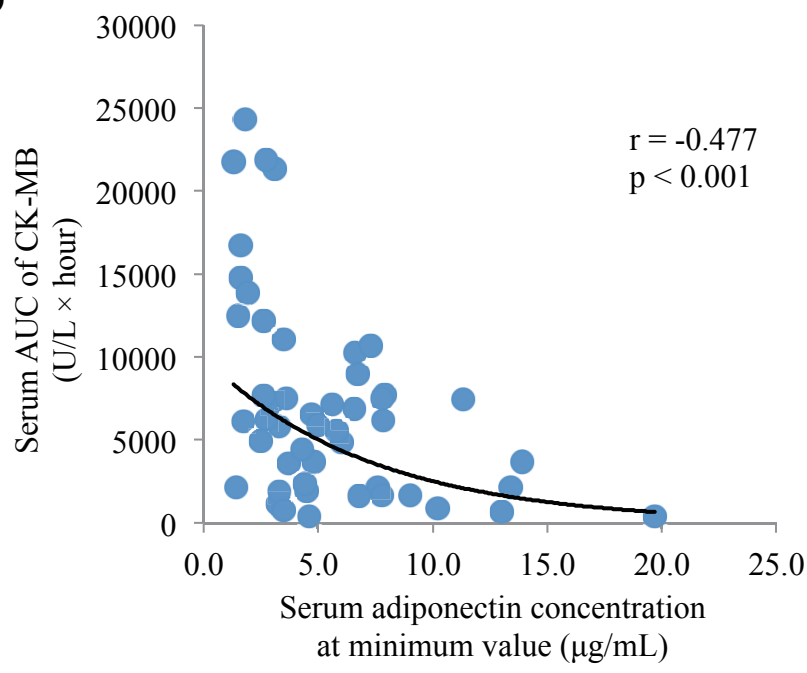

Fig. 2. Correlations between serum adiponectin concentration and AUC of CK-MB.

Serum adiponectin concentrations were shown in the horizontal axis, on admission (A), at 24 hours (B), at 168 hours (C), and at minimum value (D). CK-MB, MB fraction of creatine kinase; AUC, area under the curve

(AMPK) and cyclooxygenase (COX)-2 pathway and reducing oxidative stress ${ }^{25}$, 26). Interestingly, transplantation of scaffold-free induced adipocyte cell-sheet (iACS) derived from wild-type (WT) mice onto acute myocardial infarction heart significantly attenuated infarct size, left ventricular remodeling, and mortality compared to iACS from adiponectin knockout mice ${ }^{27)}$. In addition, intracoronary administration of adiponectin reduced myocardial infarction size ${ }^{28,29)}$. These experimental data support our hypothesis that the abundant accumulation of adiponectin onto heart tissue protects from myocardial injury, which may result in a transient decline of serum adiponecitn during acute phase. Such hypothesis fits an inverse correlation between acute decrease of serum adiponectin and AUC of CK-MB. The impact of this acute change of serum adiponectin level on cardiovascular events or mortality should be elucidated in future studies.

Currently, little is known about the relation between serum adiponectin level and myocardial infarction size. Shibata et al showed that serum adiponectin concentration was negatively correlated with infarct size measured by ${ }^{123}$ I-BMIPP scintigraphy ${ }^{30)}$, while Alkofide $\mathrm{H}$ et al. demonstrated no association between log adiponectin and infarct size ${ }^{31)}$. The present study is the first to demonstrate that serum adiponectin level on admission was one of inverse determinants in serum AUC of CK-MB (Table 2) for the first time. Determinants of myocardial infarction size have been shown, such as perfusion area of culprit coronary artery, time from onset to recanalization, collateral artery, initial TIMI grade flow, pre- and post-myocar- 
A

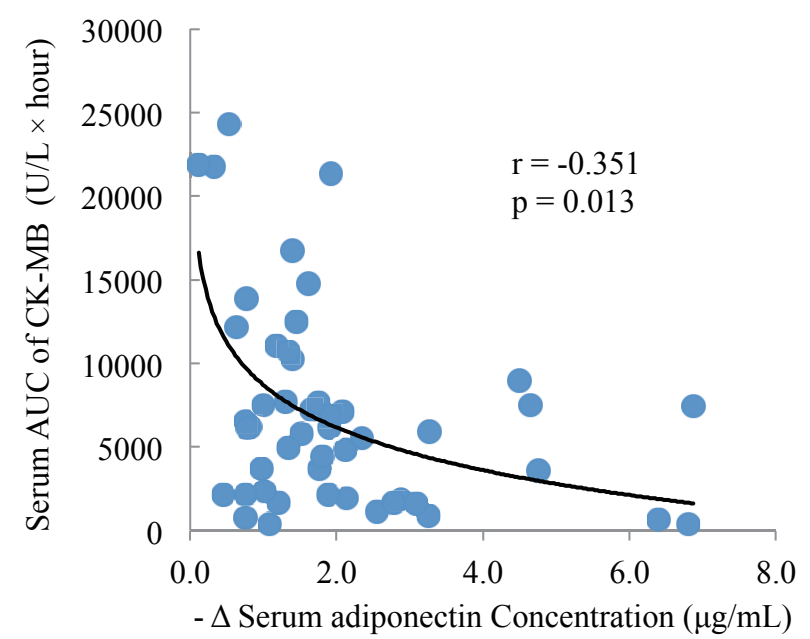

B

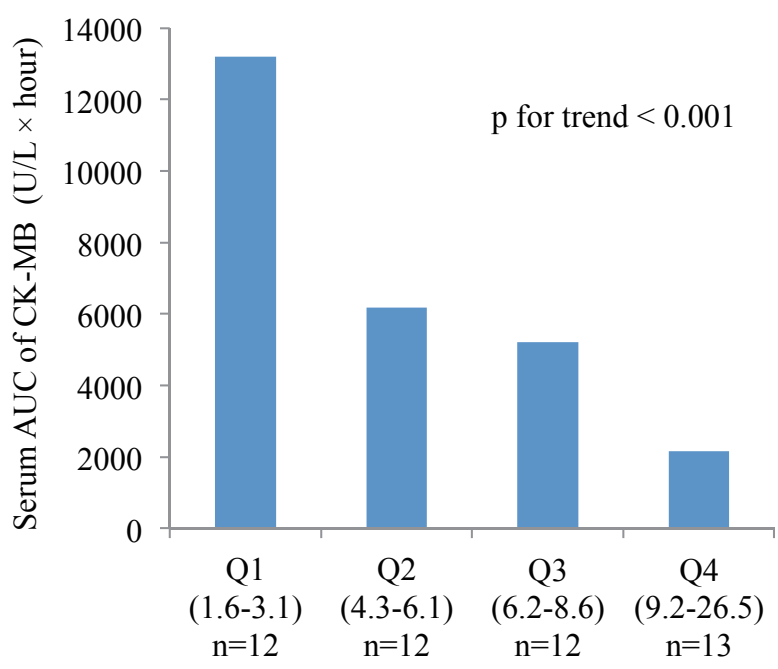

Fig.3. Impact of serum adiponectin on AUC of CK-MB.

A: Correlation between the reduction of serum adiponectin and serum AUC of CK-MB. $\Delta$ Serum adiponectin indicates the difference from baseline (on admission) to the minimum value of serum adiponectin (Min-adiponectin); $\Delta$ Serum adiponectin $=($ Min-adiponectin $)-($ baseline adiponectin). B: Serum AUC of CK-MB levels in quartile groups of serum adiponectin level on admission. Subjects were divided into 4 groups in proportion to serum adiponectin level at baseline (Q1, 1.6-3.1 $\mu \mathrm{g} / \mathrm{mL}$; Q2, 4.3-6.1 $\mu \mathrm{g} / \mathrm{mL} ; \mathrm{Q} 3,6.2-8.6 \mu \mathrm{g} / \mathrm{mL}$; Q4, 9.2-26.5 $\mu \mathrm{g} / \mathrm{mL}$ ). Shown are median values. Q1: minimum to the end of first quartile, Q2: the second quartile, Q3: the third quartile, Q4: the third quartile to maximum. CK-MB, MB fraction of creatine kinase; AUC, area under the curve

dial conditioning, and distal protection device. Similar to such factors, as previously demonstrated, collateral artery was also one of determinants in serum AUC of $\mathrm{CK}-\mathrm{MB}$ in the present study. The existence of collateral was negatively correlated with serum AUC of CK-MB (Table 2), suggesting that collateral flows reduced infarct size. As shown in Table 2, the time from onset to recanalization was not a significant determinant, probably because its time in our hospital, Senri Critical Care Medical Center, was relatively shorter than in the other medical center (124 minutes in Table 1). All enrolled subjects were also treated with PCI using distal protection device. Medications, such as GIIb/IIIa inhibitor, adenosine, and nitric oxide donors, were also demonstrated as determinants of myocardial infarction size ${ }^{32}$. There were no impacts of medication on myocardial infarction size in the present study, partly because all participants received ACE inhibitors, $\beta$-blockers, statins, and nicorandil after PCI. Administration of human atrial natriuretic peptide (hANP) reduced myocardial infarction size ${ }^{33)}$ and increased serum adiponectin level ${ }^{34,35)}$, suggesting that hANP protects from myocardial damage partly through adiponectin. However, in the present study, there was no significant impact of hANP on serum AUC of CK-MB (Table 2), probably because the number of subjects treated with hANP was small $(n=16)$ and hANP was administered after recanaliza- tion.

Increasing evidence demonstrated the anti-atherosclerotic property of adiponectin. Pischon et al. clearly showed the significant association of hypoadiponectinemia and myocardial infarction in men in a large-scale, case-controlled study in the US ${ }^{9)}$. Our previous cross-sectional study indicated that multivariateadjusted odds ratios for coronary artery diseases $(\mathrm{CAD})$ were 2.051 in subjects with hypoadiponectinemia $(<4.0 \mu \mathrm{g} / \mathrm{mL})$ compared to subjects with normal adiponectin level $(\geq 7.0 \mu \mathrm{g} / \mathrm{mL})^{10)}$. Hypoadiponectinemia was also associated with coronary lesion complexity ${ }^{11}$. As demonstrated in mouse models, adiponectin requires $\mathrm{T}$-cadherin to exhibit its protective effects and accumulate cardiovascular system ${ }^{24,36,37)}$. Interestingly, genome-wide association studies (GWAS) based on many independent cohorts demonstrated that genetic variation in $\mathrm{CDH} 13$ gene coding T-cadherin influences circulating adiponectin levels and cardiometabolic outcomes ${ }^{38-44)}$. Collectively, T-cadherinmediated accumulation of adiponectin onto the cardiovascular system may play a crucial role in cardiovascular events.

Several limitations of the present study should be considered. Serum adiponectin concentration is generally higher in women than in men ${ }^{45)}$. Culprit lesions were different in individuals, and such a difference may impact on serum CK-MB levels. The present 
Table 2. Correlations between parameters and serum AUC of CK-MB

\begin{tabular}{|c|c|c|c|c|c|c|}
\hline \multirow{2}{*}{ Parameters } & \multicolumn{6}{|c|}{ Serum AUC of CK-MB } \\
\hline & $r$ & $p$ value & $t$ value & $p$ value & $t$ value & $p$ value \\
\hline Age & -0.385 & 0.006 & -0.668 & 0.509 & & \\
\hline Male & 0.241 & 0.095 & 0.093 & 0.927 & & \\
\hline BMI & 0.205 & 0.159 & 0.447 & 0.636 & & \\
\hline Dyslipidemia & 0.194 & 0.182 & 0.228 & 0.821 & & \\
\hline Hypertension & -0.067 & 0.647 & -0.059 & 0.954 & & \\
\hline Smoking & 0.054 & 0.711 & -0.51 & 0.613 & & \\
\hline LAD as affected vessel & 0.22 & 0.128 & 1.189 & 0.243 & 1.125 & 0.267 \\
\hline Initial TIMI Flow & -0.181 & 0.214 & -1.095 & 0.281 & -1.237 & 0.223 \\
\hline Serum adiponectin on admission & -0.492 & $<0.001$ & -2.086 & 0.045 & -3.283 & 0.002 \\
\hline
\end{tabular}

BMI: body mass index, LAD: left anterior descending coronary artery, TIMI: thrombolysis in myocardial infarction trial, hANP: human atrial natriuretic peptide

study used serum AUC of CK-MB as a surrogate marker of infarct size, but myocardial infarction area should be quantified by cardiac magnetic resonance imaging (MRI), RI myocardial scintigraphy, or left ventriculography (LVG). Serum adiponectin level may be altered by some medications, such as ACE inhibitors/angiotensin II receptor blockers (ACE-I/ARB), dipeptidyl peptidase-4 inhibitors (DPP4-I), and statins, but these effects on adiponectin levels are very little compared to that of thiazolidine derivative (TZD $)^{46-48)}$. Some statins were shown to increase serum adiponectin level as a pleiotropic effect ${ }^{49,50)}$, but all subjects received statin therapy in the present study. Nine patients who were transported under cardiac arrest were excluded because CK-MB not always reflects infarct size in such a condition. Although the population size in this study was relatively small, we believe that it demonstrates a significant association between serum adiponectin and CK-MB levels in STEMI from real world data.

\section{Conclusion}

Herein, serum AUC of CK-MB in STEMI subjects treated by primary PCI was significantly associated with serum adiponectin concentration on admission and reduction of serum adiponectin levels from baseline to bottom. Data here may provide a possibility that serum adiponectin levels at acute phase are useful in the prediction for prognosis after PCI-treated
STEMI subjects, although further investigation will be needed in future.

\section{Abbreviations}

CK: creatine kinase; STEMI: ST-segment elevation myocardial infarction; PCI: percutaneous coronary intervention; AUC: area under the curve; CAD: coronary artery diseases; ACS: acute coronary syndrome; AMI: acute myocardial infarction; TIMI: Thrombolysis In Myocardial Infarction; ACE: angiotensin converting enzyme; BMI: body mass index; ELISA: enzyme-linked immunosorbent assay; RCA: right coronary artery; LMCA: left main coronary artery; LAD: left anterior descending coronary artery; LCx: left circumflex coronary artery; DES: drug eluting stent; BMS: bare metal stent; I-R: ischemia-reperfusion; AMPK: AMP-activated protein kinase; COX: cyclooxygenase; iACS: induced adipocyte cell-sheet; hANP: human atrial natriuretic peptide; RBP4: retinolbinding protein 4; TNF- $\alpha$ : tumor necrosis factor- $\alpha$; MRI: magnetic resonance imaging; LVG: left ventriculography; ARB: angiotensin II receptor blockers; DPP4-I: dipeptidyl peptidase- 4 inhibitors; TZD: thiazolidine derivative.

\section{Authors' Contributions}

T.N. acquired and analyzed data, and wrote the manuscript. N.M. conceived the study design, ana- 
lyzed data, and wrote the manuscript. T.F., S.F., Y.F., H.N., S.F., M.Y., and H.N. participated in the discussion and the interpretation of data. H.S., Y.H., T.K., and I.S. participated in the discussion and the interpretation of data, and reviewed manuscript. All authors read and approved the final version of the manuscript.

\section{Acknowledgments}

We thank Kayoko Ohashi for excellent technical assistance, especially in measurement of adiponectin. This work was supported in part by a Grant-in-Aid for Scientific Research (C) no. 25461386 (to N. M.), a Grant-in-Aid for Scientific Research (B) no. 26293221 (to T. F.), and Takeda Science Foundation (to N. M.). We also thank Dr. Matthew Lukies for English proofreading.

\section{COI}

All authors declared no conflict of interests in present study.

\section{References}

1) Matsuzawa Y, Funahashi T, Kihara S, Shimomura I: Adiponectin and metabolic syndrome. Arterioscler Thromb Vasc Biol, 2004; 24: 29-33

2) Funahashi T, Matsuzawa Y: Adiponectin and the cardiometabolic syndrome: an epidemiological perspective. Best Pract Res Clin Endocrinol Metab, 2014; 28: 93-106

3) Ouchi N: Adipocytokines in Cardiovascular and Metabolic Diseases. J Atheroscler Thromb, 2016; 23: 645-654

4) Maeda N, Funahashi T, Shimomura I: Cardiovascularmetabolic impact of adiponectin and aquaporin. Endocr J, 2013; 60: 251-259

5) Ouchi N, Kihara S, Arita Y, Maeda K, Kuriyama H, Okamoto Y, Hotta K, Nishida M, Takahashi M, Nakamura T, Yamashita S, Funahashi T, Matsuzawa Y: Novel modulator for endothelial adhesion molecules: adipocyte-derived plasma protein adiponectin. Circulation, 1999; 100: 2473-2476

6) Arita Y, Kihara S, Ouchi N, Maeda K, Kuriyama H, Okamoto Y, Kumada M, Hotta K, Nishida M, Takahashi M, Nakamura T, Shimomura I, Muraguchi M, Ohmoto Y, Funahashi T, Matsuzawa Y: Adipocyte-derived plasma protein adiponectin acts as a platelet-derived growth factor-BB-binding protein and regulates growth factorinduced common postreceptor signal in vascular smooth muscle cell. Circulation, 2002; 105: 2893-2898

7) Ouchi N, Kihara S, Arita Y, Nishida M, Matsuyama A, Okamoto Y, Ishigami M, Kuriyama H, Kishida K, Nishizawa H, Hotta K, Muraguchi M, Ohmoto Y, Yamashita S, Funahashi T, Matsuzawa Y: Adipocyte-derived plasma protein, adiponectin, suppresses lipid accumulation and class A scavenger receptor expression in human monocyte- derived macrophages. Circulation, 2001; 103: 1057-1063

8) Mori T, Koyama Y, Maeda N, Nakamura Y, Fujishima Y, Matsuda K, Funahashi T, Shimada S, Shimomura I: Ultrastructural localization of adiponectin protein in vasculature of normal and atherosclerotic mice. Sci Rep, 2014; 4: 4895

9) Pischon T, Girman CJ, Hotamisligil GS, Rifai N, Hu FB, Rimm EB: Plasma adiponectin levels and risk of myocardial infarction in men. JAMA, 2004; 291: 1730-1737

10) Kumada M, Kihara S, Sumitsuji S, Kawamoto T, Matsumoto S, Ouchi N, Arita Y, Okamoto Y, Shimomura I, Hiraoka H, Nakamura T, Funahashi T, Matsuzawa Y, Osaka CAD Study Group. Coronary artery disease: Association of hypoadiponectinemia with coronary artery disease in men. Arterioscler Thromb Vasc Biol, 2003; 23: 85-89

11) Otsuka F, Sugiyama S, Kojima S, Maruyoshi H, Funahashi T, Matsui K, Sakamoto T, Yoshimura M, Kimura K, Umemura S, Ogawa H: Plasma adiponectin levels are associated with coronary lesion complexity in men with coronary artery disease. J Am Coll Cardiol, 2006; 48: $1155-1162$

12) Kojima S, Funahashi T, Sakamoto T, Miyamoto S, Soejima H, Hokamaki J, Kajiwara I, Sugiyama S, Yoshimura M, Fujimoto K, Miyao Y, Suefuji H, Kitagawa A, Ouchi N, Kihara S, Matsuzawa Y, Ogawa H: The variation of plasma concentrations of a novel, adipocyte derived protein, adiponectin, in patients with acute myocardial infarction. Heart, 2003; 89: 667-668

13) Norris RM, Whitlock RM, Barratt-Boyes C, Small CW: Clinical measurement of myocardial infarct size. Modification of a method for the estimation of total creatine phosphokinase release after myocardial infarction. Circulation, 1975; 51: 614-620

14) Halkin A, Stone GW, Grines CL, Cox DA, Rutherford BD, Esente P, Meils CM, Albertsson P, Farah A, Tcheng JE, Lansky AJ, Mehran R: Prognostic implications of creatine kinase elevation after primary percutaneous coronary intervention for acute myocardial infarction. J Am Coll Cardiol, 2006; 47: 951-961

15) Nienhuis MB, Ottervanger JP, de Boer MJ, Dambrink JH, Hoorntje JC, Gosselink AT, Suryapranata H, van't Hof AW, Zwolle Myocardial Infarction Study Group: Prognostic importance of creatine kinase and creatine kinase-MB after primary percutaneous coronary intervention for ST-elevation myocardial infarction. Am Heart J, 2008; 155: 673-679

16) Bagai A, Schulte PJ, Granger CB, Mahaffey KW, Christenson RH, Bell G, Lopes RD, Green CL, Lincoff AM, Armstrong PW, Roe MT: Prognostic implications of creatine kinase-MB measurements in ST-segment elevation myocardial infarction patients treated with primary percutaneous coronary intervention. Am Heart J, 2014; 168: 503-511

17) The TIMI Study Group: The Thrombolysis in Myocardial Infarction (TIMI) trial. N Engl J Med, 1985; 312: 932-936

18) Rentrop KP, Cohen M, Blanke H, Phillips RA: Changes in collateral channel filling immediately after controlled coronary artery occlusion by an angioplasty balloon in human subjects. J Am Coll Cardiol, 1985; 5: 587-592 
19) Trifunovic D, Stankovic S, Marinkovic J, Beleslin B, Banovic M, Djukanovic N, Orlic D, Tesic M, VujisicTesic B, Petrovic M, Nedeljkovic I, Stepanovic J, Djordjevic-Dikic A, Giga V, Ostojic M: Time-dependent changes of plasma adiponectin concentration in relation to coronary microcirculatory function in patients with acute myocardial infarction treated by primary percutaneous coronary intervention. J Cardiol, 2015; 65: 208-215

20) Shibata R, Sato K, Kumada M, Izumiya $Y$, Sonoda $M$, Kihara S, Ouchi N, Walsh K: Adiponectin accumulates in myocardial tissue that has been damaged by ischemiareperfusion injury via leakage from the vascular compartment. Cardiovasc Res, 2007; 74: 471-479

21) Liu S, Yin T, Wei X, Yi W, Qu Y, Liu Y, Wang R, Lian K, Xia C, Pei H, Sun L, Ma Y, Lau WB, Gao E, Koch WJ, Wang H, Tao L: Downregulation of adiponectin induced by tumor necrosis factor $\alpha$ is involved in the aggravation of posttraumatic myocardial ischemia/reperfusion injury. Crit Care Med, 2011; 39: 1935-1943

22) Komura $N$, Maeda $N$, Mori $T$, Kihara $S$, Nakatsuji $H$, Hirata A, Tochino Y, Funahashi T, Shimomura I: Adiponectin protein exists in aortic endothelial cells. PLoS One, 2013; 8: e71271

23) Fujita $K$, Maeda $N$, Sonoda $M$, Ohashi $K$, Hibuse $T$, Nishizawa H, Nishida M, Hiuge A, Kurata A, Kihara S, Shimomura I, Funahashi T: Adiponectin protects against angiotensin II-induced cardiac fibrosis through activation of PPAR-alpha. Arterioscler Thromb Vasc Biol, 2008; 28: 863-870

24) Matsuda K, Fujishima Y, Maeda N, Mori T, Hirata A, Sekimoto R, Tsushima Y, Masuda S, Yamaoka M, Inoue K, Nishizawa H, Kita S, Ranscht B, Funahashi T, Shimomura I: Positive feedback regulation between adiponectin and T-cadherin impacts adiponectin levels in tissue and plasma of male mice. Endocrinology, 2015; 156: 934-946

25) Shibata R, Sato K, Pimentel DR, Takemura Y, Kihara S, Ohashi K, Funahashi T, Ouchi N, Walsh K: Adiponectin protects against myocardial ischemia-reperfusion injury through AMPK- and COX-2-dependent mechanisms. Nat Med, 2005; 11: 1096-1103

26) Tao L, Gao E, Jiao X, Yuan Y, Li S, Christopher TA, Lopez BL, Koch W, Chan L, Goldstein BJ, Ma XL: Adiponectin Cardioprotection After Myocardial Ischemia/ Reperfusion Involves the Reduction of Oxidative/Nitrative Stress. Circulation, 2007; 115: 1408-1416

27) Imanishi $Y$, Miyagawa $S$, Maeda $N$, Fukushima $S$, Kitagawa-Sakakida S, Daimon T, Hirata A, Shimizu T, Okano T, Shimomura I, Sawa Y: Induced adipocyte cellsheet ameliorates cardiac dysfunction in a mouse myocardial infarction model: a novel drug delivery system for heart failure. Circulation, 2011; 124: S10-S17

28) Kondo K, Shibata R, Unno K, Shimano M, Ishii M, Kito T, Shintani S, Walsh K, Ouchi N, Murohara T: Impact of a single intracoronary administration of adiponectin on myocardial ischemia/reperfusion injury in a pig model. Circ Cardiovasc Interv, 2010; 3: 166-173

29) Dębiński M, Buszman PP, Milewski K, Wojakowski W, Jackiewicz W, Pająk J, Szurlej D, Fryc-Stanek J, Wiernek S, Jelonek M, Spurlock ME, Martin J, Bochenek A, Buszman PE: Intracoronary adiponectin at reperfusion reduces infarct size in a porcine myocardial infarction model. Int J
Mol Med, 2011; 27: 775-781

30) Shibata R, Numaguchi $Y$, Matsushita K, Sone T, Kubota R, Ohashi T, Ishii M, Kihara S, Walsh K, Ouchi N, Murohara T: Usefulness of adiponectin to predict myocardial salvage following successful reperfusion in patients with acute myocardial infarction. Am J Cardiol, 2008; 101: $1712-1715$

31) Alkofide H, Huggins GS, Ruthazer R, Beshansky JR, Selker HP: Serum adiponectin levels in patients with acute coronary syndromes: Serial changes and relation to infarct size. Diab Vasc Dis Res, 2015; 12: 411-419

32) McAlindon E, Bucciarelli-Ducci C, Suleiman MS, Baumbach A: Infarct size reduction in acute myocardial infarction. Heart, 2015; 101: 155-160

33) Kitakaze M, Asakura M, Kim J, Shintani Y, Asanuma H, Hamasaki T, Seguchi O, Myoishi M, Minamino T, Ohara T, Nagai Y, Nanto S, Watanabe K, Fukuzawa S, Hirayama A, Nakamura N, Kimura K, Fujii K, Ishihara M, Saito Y, Tomoike H, Kitamura S, J-WIND investigators: Human atrial natriuretic peptide and nicorandil as adjuncts to reperfusion treatment for acute myocardial infarction (J-WIND): two randomised trials. Lancet, 2007; 370: 1483-1493

34) Tsukamoto O, Fujita M, Kato M, Yamazaki S, Asano Y, Ogai A, Okazaki H, Asai M, Nagamachi Y, Maeda N, Shintani Y, Minamino T, Asakura M, Kishimoto I, Funahashi T, Tomoike H, Kitakaze M: Natriuretic peptides enhance the production of adiponectin in human adipocytes and in patients with chronic heart failure. J Am Coll Cardiol, 2009; 53: 2070-2077

35) Birkenfeld AL, Boschmann M, Engeli S, Moro C, Arafat AM, Luft FC, Jordan J: Atrial natriuretic peptide and adiponectin interactions in man. PLoS One, 2012; 7: e43238

36) Denzel MS, Scimia MC, Zumstein PM, Walsh K, RuizLozano P, Ranscht B: T-cadherin is critical for adiponectin-mediated cardioprotection in mice. J Clin Invest, 2010; 120: 4342-4352

37) Parker-Duffen JL, Nakamura K, Silver M, Kikuchi R, Tigges U, Yoshida S, Denzel MS, Ranscht B, Walsh K: T-cadherin is essential for adiponectin-mediated revascularization. J Biol Chem, 2013; 288: 24886-24897

38) Ling H, Waterworth DM, Stirnadel HA, Pollin TI, Barter PJ, Kesäniemi YA, Mahley RW, McPherson R, Waeber G, Bersot TP, Cohen JC, Grundy SM, Mooser VE, Mitchell $\mathrm{BD}$ : Genome-wide linkage and association analyses to identify genes influencing adiponectin levels: the GEMS Study. Obesity, 2009; 17: 737-744

39) Chung CM, Lin TH, Chen JW, Leu HB, Yang HC, Ho HY, Ting CT, Sheu SH, Tsai WC, Chen JH, Lin SJ, Chen YT, Pan WH: A genome-wide association study reveals a quantitative trait locus of adiponectin on $\mathrm{CDH} 13$ that predicts cardiometabolic outcomes. Diabetes, 2011; 60: 2417-2423

40) Morisaki H, Yamanaka I, Iwai N, Miyamoto Y, Kokubo Y, Okamura T, Okayama A, Morisaki T: CDH13 gene coding T-cadherin influences variations in plasma adiponectin levels in the Japanese population. Hum Mutat, 2012; 33: 402-410

41) Gao H, Kim YM, Chen P, Igase M, Kawamoto R, Kim MK, Kohara K, Lee J, Miki T, Ong RT, Onuma H, Osawa H, Sim X, Teo YY, Tabara Y, Tai ES, van Dam 
RM: Genetic variation in $\mathrm{CDH} 13$ is associated with lower plasma adiponectin levels but greater adiponectin sensitivity in East Asian populations. Diabetes, 2013; 62: 4277-4283

42) Putku M, Kals M, Inno R, Kasela S, Org E, Kožich V, Milani L, Laan M: CDH13 promoter SNPs with pleiotropic effect on cardiometabolic parameters represent methylation QTLs. Hum Genet, 2015; 134: 291-303

43) Teng MS, Hsu LA, Wu S, Sun YC, Juan SH, Ko YL: Association of $\mathrm{CDH} 13$ genotypes/haplotypes with circulating adiponectin levels, metabolic syndrome, and related metabolic phenotypes: the role of the suppression effect. PLoS One, 2015; 10: e0122664

44) Kitamoto A, Kitamoto T, Nakamura T, Matsuo T, Nakata Y, Hyogo H, Ochi H, Kamohara S, Miyatake N, Kotani K, Mineo I, Wada J, Ogawa Y, Yoneda M, Nakajima A, Funahashi T, Miyazaki S, Tokunaga K, Masuzaki H, Ueno T, Chayama K, Hamaguchi K, Yamada K, Hanafusa T, Oikawa S, Sakata T, Tanaka K, Matsuzawa Y, Hotta K: CDH13 Polymorphisms are Associated with Adiponectin Levels and Metabolic Syndrome Traits Independently of Visceral Fat Mass. J Atheroscler Thromb, 2016; 23: 309-319

45) Nishizawa H, Shimomura I, Kishida K, Maeda N, Kuriyama H, Nagaretani H, Matsuda M, Kondo H, Furuyama N, Kihara S, Nakamura T, Tochino Y, Funahashi T, Matsuzawa Y: Androgens decrease plasma adiponectin, an insulin-sensitizing adipocyte-derived protein. Diabetes, 2002; 51: 2734-2741

46) Maeda N, Takahashi M, Funahashi T, Kihara S, Nishizawa H, Kishida K, Nagaretani H, Matsuda M,
Komuro R, Ouchi N, Kuriyama H, Hotta K, Nakamura T, Shimomura I, Matsuzawa Y: PPARgamma ligands increase expression and plasma concentrations of adiponectin, an adipose-derived protein. Diabetes, 2001; 50: 2094-2099

47) Kurata A, Nishizawa H, Kihara S, Maeda N, Sonoda M, Okada T, Ohashi K, Hibuse T, Fujita K, Yasui A, Hiuge A, Kumada M, Kuriyama H, Shimomura I, Funahashi T: Blockade of Angiotensin II type-1 receptor reduces oxidative stress in adipose tissue and ameliorates adipocytokine dysregulation. Kidney Int, 2006; 70: 1717-1724

48) Hibuse T, Maeda N, Kishida K, Kimura T, Minami T, Takeshita E, Hirata A, Nakagawa Y, Kashine S, Oka A, Hayashi M, Nishizawa H, Funahashi T, Shimomura I: A pilot three-month sitagliptin treatment increases serum adiponectin level in Japanese patients with type 2 diabetes mellitus--a randomized controlled trial START-J study. Cardiovasc Diabetol, 2014; 13: 96

49) Takagi T, Matsuda M, Abe M, Kobayashi H, Fukuhara A, Komuro R, Kihara S, Caslake MJ, McMahon A, Shepherd J, Funahashi T, Shimomura I: Effect of pravastatin on the development of diabetes and adiponectin production. Atherosclerosis, 2008; 196: 114-121

50) Ohashi T, Shibata R, Morimoto T, Kanashiro M, Ishii $H$, Ichimiya S, Hiro T, Miyauchi K, Nakagawa Y, Yamagishi M, Ozaki Y, Kimura T, Daida H, Murohara T, Matsuzaki M: Correlation between circulating adiponectin levels and coronary plaque regression during aggressive lipid-lowering therapy in patients with acute coronary syndrome: subgroup analysis of JAPAN-ACS study. Atherosclerosis, 2010; 212: 237-242 